\title{
Evaluation of recommended doses of meropenem in patients with augmented renal clearance, a prospective observational study
}

\author{
Fatemeh Nezarat ${ }^{1}$, Farzad Kobarfard ${ }^{1}$, Rezvan Hassanpour ${ }^{1}$, Elham Pourheidar $^{1}$, and \\ Mohammad Sistanizad ${ }^{1}$ \\ ${ }^{1}$ Shahid Beheshti University of Medical Sciences
}

July 28, 2020

\begin{abstract}
Aim: Augmented Renal Clearance (ARC) is a common phenomenon among critically ill patients and create sub-therapeutic concentrations of antibiotics, due to an increase in renal clearance of them. We evaluated the Pharmacokinetic and Pharmacodynamic (PK/PD) properties of recommended doses of meropenem in critically ill patients with ARC. Methods: Adult critically ill patients with confirmed ARC, based on 12-hour Creatinine Clearance ( $\mathrm{CrCl})([?] 130 \mathrm{ml} / \mathrm{min} / 1.73 \mathrm{~m} 2)$, who received standard doses of meropenem enrolled. Two blood samples were gathered from each participant, at the steady-state time, to determination of peak and trough concentrations. Serum concentrations of meropenem were measured by High-Performance Liquid Chromatography (HPLC) with Ultra-Violet (UV) detector. Results: From eighteen paired samples (peak and trough concentrations) that were obtained from 16 critically ill patients, peak concentrations were significantly lower in group 1 (received meropenem $1 \mathrm{~g}$ every 8 hours) than group 2 (received meropenem $2 \mathrm{~g}$ every 8 hours) (mean $\pm \mathrm{SD}, 5.95 \pm 3.39 \mu \mathrm{g} / \mathrm{mL} \mathrm{vs}$. $11.93 \pm 4.18 \mu \mathrm{g} / \mathrm{mL}$, respectively, $\mathrm{p}=0.005)$. Trough concentration were sub-threshold $(<2 \mu \mathrm{g} / \mathrm{mL})$ in 10 patients of group $1(83.3 \%)$ and 3 patients of group $2(50 \%)$. ft $>$ MIC [?] $50 \%$ was achieved in $83.3 \%$ of patients in both groups whereas $16.6 \%$ of patients of group 1 and $33.3 \%$ of patients of group 2 had $\mathrm{ft}>\mathrm{MIC}=100 \%$. Conclusion: ARC is an essential cause of sub-therapeutic concentrations of meropenem in critically ill patients, and higher than the recommended doses of meropenem administered as an intermittent infusion may be necessary to achieve the PD targets and improve efficacy.
\end{abstract}

\section{INTRODUCTION}

Augmented Renal Clearance (ARC) is a common phenomenon among critically ill patients [1-3]. The incidence of ARC, based on the studies population and definition of ARC, reported from 14 to $80 \%$ [4, 5]. ARC refers to the enhanced renal elimination of solutes and is commonly defined as Creatinine Clearance $(\mathrm{CrCl})$ [?]130 ml/min $/ 1.73 \mathrm{~m}^{2}[4,6]$. Increase in the renal clearance of drugs due to ARC, especially hydrophilic ones like $\beta$-lactams, can lead to changes in the Pharmacokinetic/Pharmacodynamic(PK/PD) properties $[4,7,8]$ and create sub-therapeutic concentrations of antibiotics as a major reason of treatment failure in critically ill patients [5, 8-11]. Nowadays, for enhancement of drug efficacy, interventions such as Therapeutic Drug Monitoring (TDM) have been suggested to achieve the optimal antimicrobial concentration [12].

Meropenem is a broad-spectrum $\beta$-lactam. Its bactericidal activity is time-dependent, and minimum plasma concentration must be maintained higher than the Minimum Inhibitory Concentration (MIC) for an adequate percentage of time in the dosing interval (\%ft $>$ MIC) to reach optimal efficacy [13-15]. According to this PD properties, studies suggested prolonged infusion of meropenem rather than increasing the dose to maximize efficacy and minimize concentration-related adverse effects [16-18].

This study aimed to evaluate the PK/PD properties of meropenem in ARC patients, receiving recommended doses as a 4-hr intermittent infusion.

\section{METHODS}




\section{Settings:}

This single-centre prospective observational cohort study was conducted at a 30-bed medical-surgical Intensive Care Unit (ICU) of Imam Hossein Medical Center, affiliated with Shahid Beheshti University of Medical Sciences (SBMU) in Tehran, Iran. This study has been approved by Institutional Review Boards of SBMU with the ethics committee code of IR.SBMU.PHARMACY.REC.1398.103.

\section{Study population:}

Inclusion criteria were ICU admitted adult patients with a confirmed ARC by 12-hour urine collection (12-hr $\mathrm{CrCl}[?] 130 \mathrm{ml} / \mathrm{min} / 1.73 \mathrm{~m}^{2}$ ) who received meropenem $1 \mathrm{~g}$ or $2 \mathrm{~g}$ every 8 hours, as an intermittent infusion over 4-hr, according to physician decision. Patients who were pregnant or lactating, or had a Serum Creatinine (Scr) [?] $1.3 \mathrm{mg} / \mathrm{dL}$ and hypersensitivity to $\beta$-lactams were excluded.

\section{Interventions:}

All ICU patients were evaluated for the risk of ARC development, using ARC and Augmented Renal Clearance in Trauma Intensive Care (ARCTIC) scoring systems (Table 1) [4, 19] on the first day of admission. For patients who categorized as high risk based on scoring systems, 12-hour urine collection was requested. Patients with confirmed ARC, based on 12-hour urine $\mathrm{CrCl}$, who received standard doses of meropenem $(1 \mathrm{~g}$ or $2 \mathrm{~g}$ every 8 hours, infused over 4 -hr) based on the physician in charge decision, enrolled in the study. After 48 hours, at the steady-state time, two blood samples gathered from each participant. The first sample obtained 60 minutes after the end of the meropenem infusion (peak concentration (Cpeak)) and the second one attained 30 minutes before receiving the next dose (trough concentration (Ctrough)). Blood samples were immediately centrifuged for $15 \mathrm{~min}$ at $4000 \mathrm{~g}$, and serum was stored at $-80^{\circ} \mathrm{C}$ for later analysis.

\section{Meropenem assay:}

The samples were analyzed at the clinical pharmacy laboratory of SBMU. The plasma concentration of meropenem was determined by a validated High-Performance Liquid Chromatography (HPLC) according to a previously reported procedure with some minor modifications [20]. In brief, sample preparation involves two-step plasma protein precipitation with acetonitrile and dichloromethane. Initially, $950 \mu \mathrm{l}$ of plasma was added to $50 \mu \mathrm{l}$ of acetaminophen $(40 \mu \mathrm{g} / \mathrm{mL})$ following the addition of $1000 \mu \mathrm{l}$ of acetonitrile. After shaking for $10 \mathrm{~min}$ by Vortex Mixer and $10 \mathrm{~min}$ centrifugation at $1000 \mathrm{~g}$ respectively, a $1000 \mu \mathrm{l}$ of supernatant was added to $1000 \mu \mathrm{l}$ methylene chloride. Finally, a $20 \mu \mathrm{l}$ of the aliquot of the upper aqueous layer was injected into the $\mathrm{C} 18$ analytical column $(250 \times 4.6 \mathrm{~mm}$ with $3.5 \mu \mathrm{m}$ spherical particles $)$ after $10 \mathrm{~min}$ shaking by Vortex Mixer and $10 \mathrm{~min}$ centrifugation at $1000 \mathrm{~g}$ in turn. The mobile phase consisted of $10.53 \mathrm{mmol} / \mathrm{L}$ ammonium acetate: acetonitrile $(91: 9, \mathrm{v} / \mathrm{v})(\mathrm{pH}=4)$ pumped at $1 \mathrm{ml} / \mathrm{min}$. The UV detector was adjusted at $298 \mathrm{~nm}$. The meropenem calibration curve was linear over the concentration range $0.25-20 \mathrm{mg} / \mathrm{L}$ with the correlation coefficient $\left(\mathrm{r}^{2}\right)=0.999$. Intra-assay accuracy ranged from $+1.38 \%$ to $+8.50 \%$ and precision was less than $.3 .06 \%$. Inter-assay accuracy ranged from $-1.28 \%$ to $+2.17 \%$ and precision was less than $.5 .42 \%$. The lower limit of quantification was $0.125 \mathrm{mg} / \mathrm{L}$.

\section{Definition and End points:}

\section{Formulas}

Urinary creatinine clearance in a 12-hour urinary collection was calculated using the below equation:

12-hour creatinine clearance $(\mathrm{ml} / \mathrm{min})=\frac{\text { urine volume }(\mathrm{mL}) \times \text { urine creatinin }\left(\frac{\mathrm{mg}}{\mathrm{dL}}\right)}{\text { serum creatinin }\left(\frac{\mathrm{mg}}{\mathrm{dL}}\right) \times \text { collectin time }(\text { min })}$

The PK parameters of meropenem were calculated according to the following equations:

$$
\begin{aligned}
& \mathrm{CL}(\mathrm{L} / \mathrm{hr})=\frac{[\text { Dose } / T]}{\text { Css ave }} \\
& \mathrm{K}\left(\mathrm{min}^{-1}\right)=\frac{\ln [\text { Cpeak } / \text { Ctrough }]}{t} \\
& \mathrm{Vd}(\mathrm{L})=\frac{\mathrm{CL}}{K}
\end{aligned}
$$


$\mathrm{T} 1 / 2(\mathrm{hr})=\frac{0.693}{K}$

"CL" is clearance of meropenem, " $\mathrm{K}$ " is elimination rate constant and" T1/2" is terminal half-life. Css ave is the average steady-state concentration of meropenem. " is the dosing interval and " $t$ " is the time interval between the measurements of Cpeak and Ctrough.

\section{Endpoints}

The European Committee on Antimicrobial Susceptibility Testing (EUCAST) determined $2 \mu \mathrm{g} / \mathrm{mL}$ of meropenem as a susceptible breakpoint of meropenem for the Gram-negative organisms (MIC). The primary pharmacodynamic endpoint of this study was the concentrations above the breakpoints for [?] $50 \%$ of the dosing interval ( $\mathrm{ft}>\mathrm{MIC}$ [?] 50\%), and the secondary endpoint was $\mathrm{ft}>\mathrm{MIC}=100 \%$.

\section{Statistical analysis:}

All statistical analyses were performed using SPSS for Windows (Version 21.0; SPSS Inc., Chicago, IL, USA). Quantitative data were tested for normality of distributions by Kolmogorov-Smirnov test, and then compared by Unpaired Student's $t$-test, Mann-Whitney U test for normal and non-normal data, respectively. Qualitative data were analyzed by the Chi-square test, and a P-value of $<0.05$ was considered as significant.

\section{RESULTS}

From a total of 819 critically ill patients who admitted to the ICU from July 23, 2018, to March 19, 2019, 79 patients were ARC positive, according to $12-\mathrm{hr} \mathrm{CrCl}$, and 16 subjects received meropenem. Twelve patients received meropenem with a dose of $1 \mathrm{~g}$ every 8 hours (group 1), and the remaining four subjects received $2 \mathrm{~g}$ every 8 hours (group 2). During the treatment period, the dose of meropenem increased from 1 g every 8 hours to $2 \mathrm{~g}$ every 8 hours, according to their physician decision, for two patients in group 1 . We gathered blood samples of them after achieving steady-state based on drug half-life. Overall we collected 18 paired samples (peak and trough concentrations) for analyzes that 12 samples were for group 1, and 6 samples were for group 2. We were detailed data in Figure 1.

Baseline characteristics including age, sex, Ideal Body Weight (IBW), ICU diagnosis on admission based on International Classification of Diseases-10 (ICD10) codes, Sequential Organ Failure Assessment (SOFA), $\mathrm{ARC}$ and ARCTIC score, 12-hr $\mathrm{CrCl}$ were recorded for participants. There were statistically significant differences in sex, ICU diagnosis and ARCTIC score between two groups ( $\mathrm{p}=0.001,0.017,0.030$, respectively). The results are shown in Table2.

The mean $\pm \mathrm{SD}$ of the PK parameters are shown in Table 3 and Figure 2. There were no statistically significant differences in the parameters between the two groups, except Cpeak. The peak concentrations was significantly lower in group 1 than group 2 (mean $\pm \mathrm{SD}: 5.95 \pm 3.39 \mu \mathrm{g} / \mathrm{mL}$ vs $11.93 \pm 4.18 \mu \mathrm{g} / \mathrm{mL}$, respectively); $\mathrm{t}(16)=-3.273, p=0.005$ (Figure $2 \mathrm{~B})$. The mean $\pm \mathrm{SD}$ of trough concentrations was $1.32 \pm$ $1.01 \mu \mathrm{g} / \mathrm{mL}$ in group 1 and $2.37 \pm 2.08 \mu \mathrm{g} / \mathrm{mL}$ in group 2 (Figure $2 \mathrm{~A}$ ).

In 13 out of 18 samples (72\%), trough level was less than $<2 \mu \mathrm{g} / \mathrm{mL}$ (sub-therapeutic) that 10 of them were in group 1 (83\% of 12 trough concentrations) and 3 of them were in group 2 (50\% of 6 trough concentrations)(Figure 3A). ft $>$ MIC [?] $50 \%$ was achieved in 10 patients of group 1(83.3\%) and 5 patients of group $2(83.3 \%)$ whereas 2 patients of group $1(16.6 \%)$ and 2 patients of group $2(33.3 \%)$ had $\mathrm{ft}>\mathrm{MIC}=100 \%$ (Figure 3B).

\section{DISCUSSION}

This study has shown that ARC was associated with lower concentrations and a higher risk of not achieving PD targets in critically ill patients even when administering meropenem by intermittent infusion (infused over 4 - $\mathrm{hr}$ ) since that, $77.7 \%$ and $16.6 \%$ of all samples not attained to $100 \% \mathrm{ft}>\mathrm{MIC}$ and $50 \% \mathrm{ft}>\mathrm{MIC}$, respectively. In group 1(3g daily), $83.3 \%$ and $16.6 \%$ of patients do not achieved $100 \% \mathrm{ft}>\mathrm{MIC}$ and $50 \% \mathrm{ft}>\mathrm{MIC}$, respectively. In accordance with this consequence, previous studies with Carlier et al ., have demonstrated 
that $76 \%$ and $37 \%$ of critically ill patients with ARC, who received meropenem $1 \mathrm{~g}$ every 8 hours as a 3 -hr infusion, did not achieve $100 \% \mathrm{ft}>\mathrm{MIC}$ and $50 \% \mathrm{ft}>\mathrm{MIC}$, respectively [21].

In the prospective observational study, Ehmann and colleagues mentioned that target attained, $50 \% \mathrm{ft}>\mathrm{MIC}$ and $100 \% \mathrm{ft}>$ MIC, for Gram-negative pathogens with MIC $2 \mu \mathrm{g} / \mathrm{mL}$, was zero percent in critically ill patients with ARC with the administration of meropenem $1 \mathrm{~g}$ every 8 hours infused over 30 minutes and concluded that increasing dose or increasing infusion time could increase the number of patients who achieve to therapeutic targets [22]. A comparison of our findings with the mentioned study confirmed prolonged infusion (4-hr vs. 30 minutes) and higher doses (6g daily vs. $3 \mathrm{~g}$ daily) increase the likelihood of achieving the target plasma concentrations.

Studies have shown that $40 \%$ to $70 \% \mathrm{ft}>\mathrm{MIC}$ is necessary for time-dependent antibiotics such as meropenem to treat infections [23]. However, many studies in critically ill patients demonstrated that to maximize the effect of $\beta$-lactam antibiotics, it is better to increase the $\mathrm{ft}$ to $100 \%(100 \% \mathrm{ft}>\mathrm{MIC})$ or to maintain the concentration four times the MIC for the entire dosing interval $(100 \% \mathrm{ft}>4 \mathrm{MIC})[24,25]$. In our study, we did not achieve $100 \% \mathrm{ft}>4 \mathrm{MIC}$ in all samples, even in group 2 (6g daily), with 4 -hr infusion in critically ill patients with ARC. Vd of meropenem in critically ill patients with ARC increased in comparison with healthy volunteers (reported Vd in our study and healthy volunteers were 77.15-118.02 L vs. 15-20 L, respectively) [26]. This result is in accordance with other studies in critically ill patients [27, 28].

Also, clearance of meropenem obtained from healthy volunteers was $7.82 \mathrm{~L} / \mathrm{hr}$ [16], but, in our study clearance increased due to augmented renal perfusion in patients with ARC $(41.25-42.85 \mathrm{~L} / \mathrm{hr})$, this is higher than those reported by other studies in critically ill patients (4.7 to $15.4 \mathrm{~L} /$ hour) [27, 28].

Another finding of our study was increased Vd in our subjects, which could reduce the concentration of time-dependent antibiotics such as meropenem. Due to the relationship between Vd and the loading dose (LD), the use of aggressive LD suggested in critically ill patients with ARC to overwhelm increased Vd [29]. The correlation between the clearance of meropenem and renal clearance has been proven [28]. Therefore, increases in renal clearance can lead to a decrease in concentrations. Low serum concentrations of meropenem in our study confirms these results [21, 30], so, because of the relationship between maintenance dose (MD) and clearance, MD can be initiated higher than the recommended doses of meropenem in critically ill patients with ARC [21, 31].

In coclusion, ARC is an essential cause of sub-therapeutic concentrations of meropenem in critically ill patients, and higher than the recommended doses of meropenem administered as an intermittent infusion may be necessary to achieve the PD targets and improve efficacy.

\section{Acknowledgments}

The authors thank Nahid Shahsavari (Clinical Pharmacy laboratory, faculty of Pharmacy, Shahid Beheshti University of Medical Science (SBMU)) for her skilled technical assistance during the set-up of HPLC method.

\section{Authors' contributions}

MS, EP, RH designed the study. Literature review, drafting of the proposal and searching were done by MS, FN, EP and RH. RH, EP helped to gather the data.

FK and FN set-up and interpretated the HPLC method and results. MS, RH and EP analyzed and interpreted data. All authors helped to manuscript improvement and finalized the article for publication.

\section{Conflicts of interest}

The authors declare that there are no conflicts of interest

\section{Funding}

This research did not receive any specific grant from funding agencies in the public, commercial, or not-forprofit sectors. 


\section{Data availability}

The data that support the findings of this study are available upon reasonable request from the corresponding author, Mohammad Sistanizad. The data are not publicly available due to the containing information that could compromise the privacy of research participants

\section{REFERENCES}

1. Fuster-Lluch O, Geronimo-Pardo M, Peyro-Garcia R, Lizan-Garcia M. Glomerular hyperfiltration and albuminuria in critically ill patients. Anaesthesia and intensive care 2008; 36: 674-80.

2. Udy AA, Jarrett P, Lassig-Smith M, Stuart J, Starr T, Dunlop R, Deans R, Roberts JA, Senthuran S, Boots R. Augmented renal clearance in traumatic brain injury: a single-center observational study of atrial natriuretic peptide, cardiac output, and creatinine clearance. Journal of neurotrauma 2017; 34: 137-44.

3. Conil J, Georges B, Lavit M, Seguin T, Tack I, Samii K, Chabanon G, Houin G, Saivin S. Pharmacokinetics of ceftazidime and cefepime in burn patients: the importance of age and creatinine clearance. International journal of clinical pharmacology and therapeutics 2007; 45: 529-38.

4. Mahmoud SH, Shen C. Augmented renal clearance in critical illness: an important consideration in drug dosing. Pharmaceutics 2017; 9: 36.

5. Ruiz S, Minville V, Asehnoune K, Virtos M, Georges B, Fourcade O, Conil J-M. Screening of patients with augmented renal clearance in ICU: taking into account the CKD-EPI equation, the age, and the cause of admission. Annals of intensive care 2015; 5: 49.

6. Claus BO, Hoste EA, Colpaert K, Robays H, Decruyenaere J, De Waele JJ. Augmented renal clearance is a common finding with worse clinical outcome in critically ill patients receiving antimicrobial therapy. Journal of critical care 2013; 28: 695-700.

7. Cook AM, Hatton-Kolpek J. Augmented renal clearance. Pharmacotherapy: The Journal of Human Pharmacology and Drug Therapy 2019; 39: 346-54.

8. Carrie C, Bentejac M, Cottenceau V, Masson F, Petit L, Cochard J-F, Sztark F. Association between augmented renal clearance and clinical failure of antibiotic treatment in brain-injured patients with ventilatoracquired pneumonia: a preliminary study. Anaesthesia Critical Care \& Pain Medicine 2018; 37: 35-41.

9. Conil J-M, Georges B, Mimoz O, Dieye E, Ruiz S, Cougot P, Samii K, Houin G, Saivin S. Influence of renal function on trough serum concentrations of piperacillin in intensive care unit patients. Intensive care medicine 2006; 32: 2063-66.

10. De Waele JJ, Lipman J, Akova M, Bassetti M, Dimopoulos G, Kaukonen M, Koulenti D, Martin C, Montravers P, Rello J. Risk factors for target non-attainment during empirical treatment with $\beta$-lactam antibiotics in critically ill patients. Intensive care medicine 2014; 40: 1340-51.

11. Wu C-C, Tai C-H, Liao W-Y, Wang C-C, Kuo C-H, Lin S-W, Ku S-C. Augmented renal clearance is associated with inadequate antibiotic pharmacokinetic/pharmacodynamic target in Asian ICU population: a prospective observational study. Infection and drug resistance 2019; 12: 2531.

12. Ohata Y, Tomita Y, Nakayama M, Tamura K, Tanigawara Y. Optimal treatment schedule of meropenem for adult patients with febrile neutropenia based on pharmacokinetic-pharmacodynamic analysis. Journal of Infection and Chemotherapy 2011; 17: 831-41.

13. Kees MG, Minichmayr IK, Moritz S, Beck S, Wicha SG, Kees F, Kloft C, Steinke T. Population pharmacokinetics of meropenem during continuous infusion in surgical ICU patients. Journal of clinical pharmacology 2016; 56: 307-15.

14. Nicolau DP. Pharmacokinetic and pharmacodynamic properties of meropenem. Clinical infectious diseases : an official publication of the Infectious Diseases Society of America 2008; 47 Suppl 1: S32-40. 
15. Taccone FS, Laterre P-F, Dugernier T, Spapen H, Delattre I, Wittebole X, De Backer D, Layeux B, Wallemacq P, Vincent J-L, Jacobs F. Insufficient $\beta$-lactam concentrations in the early phase of severe sepsis and septic shock. Critical Care 2010; 14: R126.

16. Jaruratanasirikul S, Sriwiriyajan S. Comparison of the pharmacodynamics of meropenem in healthy volunteers following administration by intermittent infusion or bolus injection. The Journal of antimicrobial chemotherapy 2003; 52: 518-21.

17. Yu Z, Pang X, Wu X, Shan C, Jiang S. Clinical outcomes of prolonged infusion (extended infusion or continuous infusion) versus intermittent bolus of meropenem in severe infection: A meta-analysis. PloS one $2018 ; 13$.

18. Craig WA. Basic pharmacodynamics of antibacterials with clinical applications to the use of $\beta$-lactams, glycopeptides, and linezolid. Infectious Disease Clinics 2003; 17: 479-501.

19. Udy AA, Roberts JA, Shorr AF, Boots RJ, Lipman J. Augmented renal clearance in septic and traumatized patients with normal plasma creatinine concentrations: identifying at-risk patients. Critical Care 2013; 17: R35.

20. Elkhaïli H, Niedergang S, Pompei D, Linger L, Leveque D, Jehl F. High-performance liquid chromatographic assay for meropenem in serum. Journal of Chromatography B: Biomedical Sciences and Applications 1996; 686: 19-26.

21. Carlier M, Carrette S, Roberts JA, Stove V, Verstraete A, Hoste E, Depuydt P, Decruyenaere J, Lipman $\mathrm{J}$, Wallis SC. Meropenem and piperacillin/tazobactam prescribing in critically ill patients: does augmented renal clearance affect pharmacokinetic/pharmacodynamic target attainment when extended infusions are used? Critical care 2013; 17: R84.

22. Ehmann L, Zoller M, Minichmayr IK, Scharf C, Maier B, Schmitt MV, Hartung N, Huisinga W, Vogeser M, Frey L. Role of renal function in risk assessment of target non-attainment after standard dosing of meropenem in critically ill patients: a prospective observational study. Critical care 2017; 21: 263.

23. Roberts JA, Paul SK, Akova M, Bassetti M, De Waele JJ, Dimopoulos G, Kaukonen K-M, Koulenti D, Martin C, Montravers P, Rello J, Rhodes A, Starr T, Wallis SC, Lipman J, Study D, Roberts JA, Lipman J, Starr T, Wallis SC, Paul SK, Margarit Ribas A, De Waele JJ, De Crop L, Spapen H, Wauters J, Dugernier T, Jorens P, Dapper I, De Backer D, Taccone FS, Rello J, Ruano L, Afonso E, Alvarez-Lerma F, GraciaArnillas MP, Fernández F, Feijoo N, Bardolet N, Rovira A, Garro P, Colon D, Castillo C, Fernado J, Lopez MJ, Fernandez JL, Arribas AM, Teja JL, Ots E, Carlos Montejo J, Catalan M, Prieto I, Gonzalo G, Galvan B, Blasco MA, Meyer E, Del Nogal F, Vidaur L, Sebastian R, Garde PM, Martin Velasco MdM, Zaragoza Crespo R, Esperatti M, Torres A, Montravers P, Baldesi O, Dupont H, Mahjoub Y, Lasocki S, Constantin JM, Payen JF, Martin C, Albanese J, Malledant Y, Pottecher J, Lefrant J-Y, Jaber S, Joannes-Boyau O, Orban C, Ostermann M, McKenzie C, Berry W, Smith J, Lei K, Rubulotta F, Gordon A, Brett S, Stotz M, Templeton M, Rhodes A, Ebm C, Moran C, Kaukonen K-M, Pettilä V, Dimopoulos G, Koulenti D, Xristodoulou A, Theodorou V, Kouliatsis G, Sertaridou E, Anthopoulos G, Choutas G, Rantis T, Karatzas S, Balla M, Papanikolaou M, Myrianthefs P, Gavala A, Fildisis G, Koutsoukou A, Kyriakopoulou M, Petrochilou K, Kompoti M, Michalia M, Clouva-Molyvdas F-M, Gkiokas G, Nikolakopoulos F, Psychogiou V, Malliotakis P, Akoumianaki E, Lilitsis E, Koulouras V, Nakos G, Kalogirou M, Komnos A, Zafeiridis T, Chaintoutis C, Arvaniti K, Matamis D, Chaintoutis C, Kydona C, Gritsi-Gerogianni N, Giasnetsova T, Giannakou M, Soultati I, Chytas I, Antoniadou E, Antipa E, Lathyris D, Koukoubani T, Paraforou T, Spiropoulou K, Bekos V, Spring A, Kalatzi T, Nikolaou H, Laskou M, Strouvalis I, Aloizos S, Kapogiannis S, Soldatou O, Bassetti M, Adembri C, Villa G, Giarratano A, Maurizio Raineri S, Cortegiani A, Montalto F, Strano MT, Ranieri VM, Sandroni C, De Pascale G, Molin A, Pelosi P, Montagnani L, Urbino R, Mastromauro I, De Rosa FG, Ranieri VM, Cardoso T, Afonso S, Gonçalves-Pereira J, Baptista JP, Akova M, Özveren A. DALI: Defining Antibiotic Levels in Intensive Care Unit Patients: Are Current $\beta$-Lactam Antibiotic Doses Sufficient for Critically Ill Patients? Clinical Infectious Diseases 2014; 58: 1072-83. 
24. Li C, Du X, Kuti JL, Nicolau DP. Clinical Pharmacodynamics of Meropenem in Patients with Lower Respiratory Tract Infections. Antimicrobial Agents and Chemotherapy 2007; 51: 1725-30.

25. McKinnon PS, Paladino JA, Schentag JJ. Evaluation of area under the inhibitory curve (AUIC) and time above the minimum inhibitory concentration $(<\mathrm{em}>\mathrm{T}</ \mathrm{em}>\& \mathrm{gt}$; MIC) as predictors of outcome for cefepime and ceftazidime in serious bacterial infections. International Journal of Antimicrobial Agents 2008; 31: $345-51$.

26. Wiseman LR, Wagstaff AJ, Brogden RN, Bryson HM. Meropenem. Drugs 1995; 50: 73-101.

27. Mattioli F, Fucile C, Del Bono V, Marini V, Parisini A, Molin A, Zuccoli ML, Milano G, Danesi R, Marchese A, Polillo M, Viscoli C, Pelosi P, Martelli A, Di Paolo A. Population pharmacokinetics and probability of target attainment of meropenem in critically ill patients. European journal of clinical pharmacology 2016; 72: 839-48.

28. Gonçalves-Pereira J, Póvoa P. Antibiotics in critically ill patients: a systematic review of the pharmacokinetics of $\beta$-lactams. Critical Care 2011; 15: R206.

29. Petersson J, Giske C, Eliasson E. Standard dosing of piperacillin and meropenem fail to achieve adequate plasma concentrations in ICU patients. Acta Anaesthesiologica Scandinavica 2016; 60: 1425-36.

30. Tröger U, Drust A, Martens-Lobenhoffer J, Tanev I, Braun-Dullaeus RC, Bode-Böger SM. Decreased meropenem levels in Intensive Care Unit patients with augmented renal clearance: benefit of therapeutic drug monitoring. International Journal of Antimicrobial Agents 2012; 40: 370-72.

31. Kothekar AT, Divatia JV, Myatra SN, Patil A, Krishnamurthy MN, Maheshwarappa HM, Siddiqui SS, Gurjar M, Biswas S, Gota V. Clinical pharmacokinetics of 3-h extended infusion of meropenem in adult patients with severe sepsis and septic shock: implications for empirical therapy against Gram-negative bacteria. Annals of Intensive Care 2020; 10: 4.

Table 1. The ARC risk scoring systems [4]

\begin{tabular}{lll}
\hline & ARC Scoring System & ARCTIC Scoring System \\
\hline Criteria & Age 50 or younger $=6 \mathrm{pts}$ & $\mathrm{SCr}<0.7 \mathrm{mg} / \mathrm{dL}=3 \mathrm{pts}$ Male sex \\
& Trauma $=3$ pts SOFA score $\leq 4$ & $=2 \mathrm{pts}$ Age $<56$ years $=4 \mathrm{pts}$ \\
& $=1 \mathrm{pt}$ & Age: $56-75$ years $=3 \mathrm{pts}$ \\
Interpretation & $0-6$ points $=$ low ARC risk $7-10$ & {$[?] 6$ points $=$ low ARC risk $>6$} \\
& points $=$ high ARC risk & points $=$ high ARC risk \\
\hline
\end{tabular}

$\mathrm{ARC}=$ Augmented renal clearance(ARC);Augmented Renal Clearance In Trauma Intensive Care (ARCTIC); Sequential Organ Failure Assessment score(SOFA);Serum creatinine concentration(Scr); point(pt)

Table 2.Demographic data

\begin{tabular}{|c|c|c|c|c|c|c|c|}
\hline & & & Groups & Groups & Groups & Groups & $\operatorname{sig}^{a, b, c}$ \\
\hline & & & $\begin{array}{l}\text { Group1: } \\
\text { 1g every } \\
8 \text { hours } \\
\text { Count }\end{array}$ & $\begin{array}{l}\text { Group1: } \\
\text { 1g every } \\
8 \text { hours } \\
\text { Mean } \pm \\
\text { SD }^{d}\end{array}$ & $\begin{array}{l}\text { Group2: } \\
2 \mathrm{~g} \text { every } \\
8 \text { hours } \\
\text { Count }\end{array}$ & $\begin{array}{l}\text { Group2: } \\
2 \mathrm{~g} \text { every } \\
8 \text { hours } \\
\text { Mean } \pm \\
\text { SD }^{d}\end{array}$ & \\
\hline Sex & Sex & $\begin{array}{l}\text { Male } \\
\text { Female }\end{array}$ & $\begin{array}{l}10 \\
2\end{array}$ & & $\begin{array}{l}6 \\
0\end{array}$ & & 0.001 \\
\hline Age & Age & Age & 12 & $36 \pm 9.70$ & 6 & $\begin{array}{l}33.50 \pm \\
10.73\end{array}$ & 0.625 \\
\hline
\end{tabular}




\begin{tabular}{|c|c|c|c|c|c|c|c|}
\hline & & & Groups & Groups & Groups & Groups & $\operatorname{sig}^{a, b, c}$ \\
\hline $\mathrm{IBW}^{\mathrm{e}}$ & $\mathrm{IBW}^{\mathrm{e}}$ & IBW $^{\mathrm{e}}$ & & $\begin{array}{l}66.67 \pm \\
9.30\end{array}$ & & $\begin{array}{l}72.73 \pm \\
5.42\end{array}$ & 0.251 \\
\hline \multirow{5}{*}{$\begin{array}{l}\text { ICU } \\
\text { diagnosis } \\
\text { on ad- } \\
\text { mission } \\
\text { day } \\
\text { based on } \\
\text { ICD10 } \\
\text { code }^{\text {f }}\end{array}$} & $\mathbf{T}$ & $\mathbf{T}$ & 6 & & 3 & & 0.017 \\
\hline & $\mathbf{G}$ & $\mathbf{G}$ & 1 & & 0 & & \\
\hline & I & I & 3 & & 1 & & \\
\hline & B & B & 2 & & 1 & & \\
\hline & $\mathbf{K}$ & $\mathbf{K}$ & 0 & & 1 & & \\
\hline $\begin{array}{l}\text { SOFAg } \\
\text { score }\end{array}$ & $\begin{array}{l}\text { SOFA }^{g} \\
\text { score }\end{array}$ & $\begin{array}{l}\text { SOFA }^{g} \\
\text { score }\end{array}$ & & $\begin{array}{l}4.50 \pm \\
2.11\end{array}$ & & $\begin{array}{l}5.67 \pm \\
0.52\end{array}$ & 0.095 \\
\hline $\begin{array}{l}\text { ARCh } \\
\text { score }\end{array}$ & $\begin{array}{l}\text { ARC } \\
\text { score }\end{array}$ & $\begin{array}{l}\text { ARC } \\
\text { score }\end{array}$ & & $\begin{array}{l}7.42 \pm \\
2.84\end{array}$ & & $\begin{array}{l}7.50 \pm \\
1.64\end{array}$ & 0.208 \\
\hline $\begin{array}{l}\text { ARCTIC } \\
\text { score }\end{array}$ & $\begin{array}{l}\text { ARCTIC } \\
\text { score }\end{array}$ & $\begin{array}{l}\text { ARCTIC } \\
\text { score }\end{array}$ & & $6.67 \pm$ & & $\begin{array}{l}7.50 \pm \\
1.64\end{array}$ & 0.030 \\
\hline $12-\mathrm{hr}$ & $12-\mathrm{hr}$ & $12-\mathrm{hr}$ & & $181.57 \pm$ & & $188.48 \pm$ & 0.851 \\
\hline $\mathrm{CrCl}^{\mathrm{j}}$ & $\mathrm{CrCl}^{\mathrm{j}}$ & $\mathrm{CrCl}^{\mathrm{j}}$ & & 57.97 & & 64.45 & \\
\hline
\end{tabular}

a, unpaired t-test; b, Mann-Whitney U test; c, chi-square test; d, Standard Deviation ;e, Ideal Body Weight(Kg); f, ICD 10 code definition: "B: Certain infections,G: Diseases of nervous system, I: Disease of circulatory system, K: Disease of digestive system, T: Injury to different part of body region."; g, Sequential Organ Failure Assessment (SOFA);h, Augmented Renal Clearance (ARC); i, Augmented Renal Clearance in Trauma Intensive Care (ARCTIC); $\mathbf{j}$, creatinine clearance of 12-hour urine collection $(\mathrm{ml} / \mathrm{min}$ )

Table3. Pharmacokinetic data

\begin{tabular}{llll}
\hline & Groups & Groups & sig $^{\mathrm{a}, \mathrm{b}}$ \\
\hline & Group1: 1g every 8 hours & Group2: 2g every 8 hours & \\
& Mean $\pm \mathbf{S D}^{\mathbf{c}}$ & Mean $\pm \mathbf{S D}^{\mathbf{c}}$ & \\
$\mathbf{C L}^{\mathbf{d}}$ & $42.85 \pm 18.3$ & $41.25 \pm 19.75$ & 0.867 \\
$\mathbf{K}^{\mathbf{e}}$ & $0.0077 \pm 0.0036$ & $0.0090 \pm 0.0031$ & 0.465 \\
$\mathbf{V d}^{\mathbf{f}}$ & $118.02 \pm 92.47$ & $77.15 \pm 22.95$ & 0.553 \\
$\mathbf{T 1}^{\mathbf{1}} \mathbf{2}^{\mathbf{g}}$ & $1.90 \pm 1.20$ & $1.45 \pm 0.653$ & 0.261 \\
$\mathbf{F t}$ & $72.80 \pm 20.15$ & $84.04 \pm 21.16$ & 0.288 \\
\hline
\end{tabular}

a, unpaired t-test; b, Mann-Whitney U test; ; c, Standard Deviation (SD); d, Total clearance(L/hr);e, Elimination rate constant $\left(\mathrm{min}^{-1}\right)$;f, Volume of distribution (L);g, Elimination half-life (hr); h, Fraction of time $>$ MIC(Mimimum Inhibitory Concentration, $2 \mu \mathrm{g} / \mathrm{mL})(\%)$.

Figure Legend

Figure 1. Participant inclusion process.

CKD: Chronic Kidney Disease; AKI: Acute Kidney Injury; RRT: Renal Replacement Therapy; ARC: Augmented Renal Clearance; ARCTIC: Augmented Renal Clearance in Trauma Intensive Care; CrCl: Creatinine 


\section{Clearance}

Figure 2. Comparison of meropenem blood levels in two groups.

$2 \mathrm{~A}$ : trough concentration $(\mu \mathrm{g} / \mathrm{mL}), 2 \mathrm{~B}$ : peak concentration $(\mu \mathrm{g} / \mathrm{mL})$.

Figure3. Creatinine Clearance $(\mathrm{CrCl})$ and meropenem trough concentration $(3 \mathrm{~A})$ and $\mathrm{ft}>\mathrm{MIC}(3 \mathrm{~B})$.

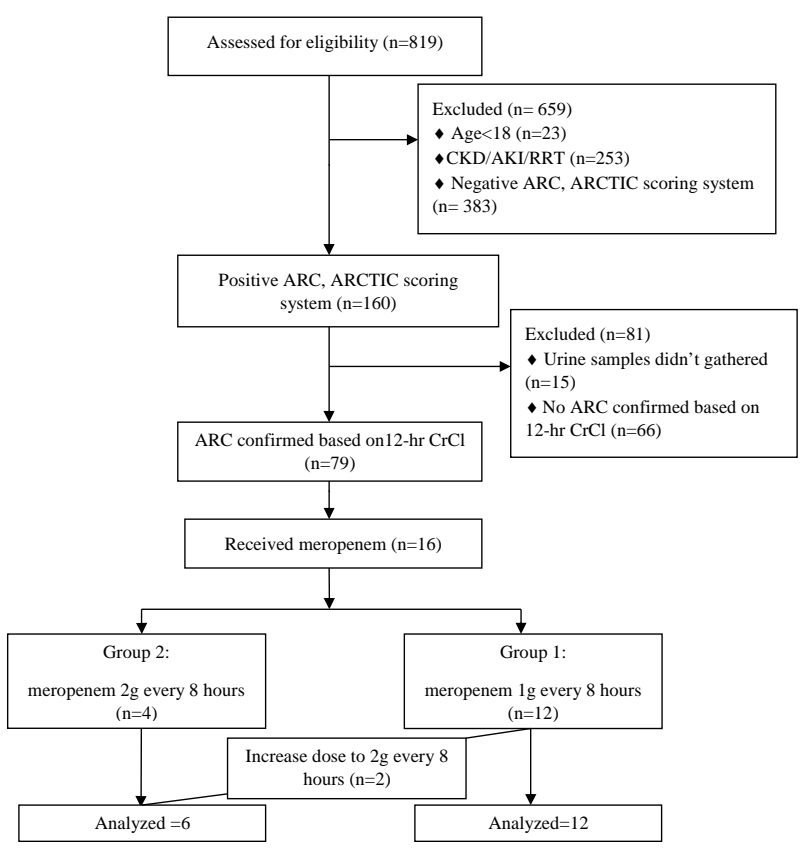

Figure 1. 

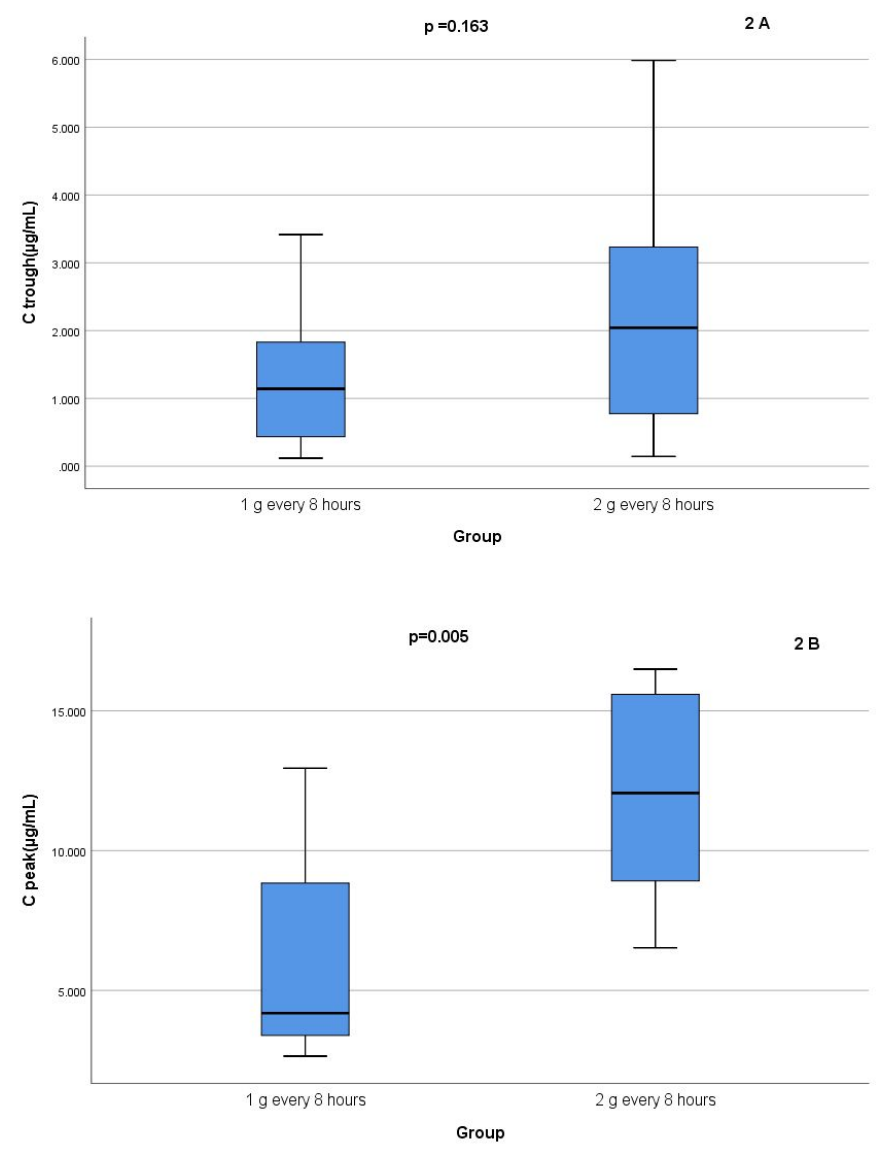

Figure 2. 

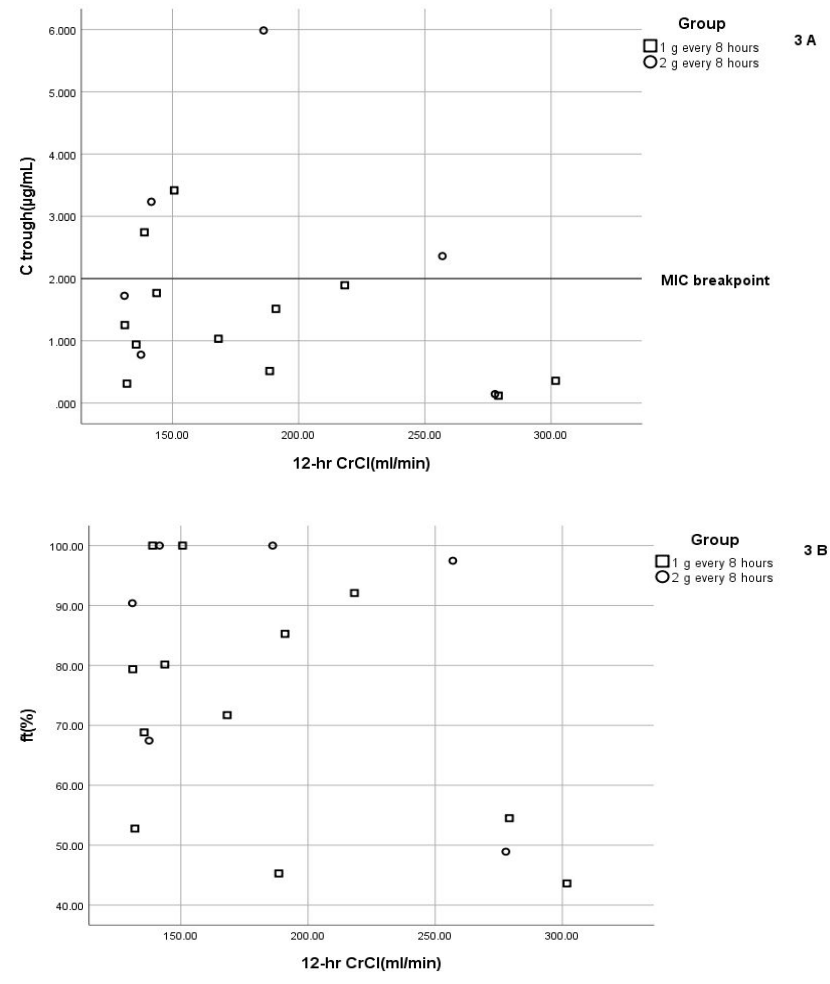

Figure3. 